\title{
Analysis of Water Retention Capacity for Select Forest Soils in Poland
}

\author{
Piotr Hewelke', Tomasz Gnatowski ${ }^{1}$, Edyta Hewelke ${ }^{2 *}$, Jan Tyszka ${ }^{3}$, Stanisław Żakowicz ${ }^{1}$ \\ 'Department of Environmental Improvement, Faculty of Civil and Environmental Engineering, \\ Warsaw University of Life Sciences - SGGW, Nowoursynowska 159, 02-776 Warsaw, Poland \\ ${ }^{2}$ Laboratory - Water Center, Faculty of Civil and Environmental Engineering, \\ Warsaw University of Life Sciences - SGGW, Ciszewskiego 6, 02-776 Warsaw, Poland \\ ${ }^{3}$ Department of Forest Ecology, Forest Research Institute, \\ Sękocin Stary, Braci Leśnej 3, 05-090 Raszyn, Poland
}

Received: 14 February 2014

Accepted: 28 October 2014

\begin{abstract}
Our paper presents an analysis of the water retention characteristics of mineral soils for select forest soils in Poland. Direct measurement of the soil retention characteristics is relatively complicated and time consuming, therefore often indirect methods are sought instead. The main objective of the paper was to establish statistical relationships between the soil basic physical properties and the moisture content at predefined soil matrix potentials (e.g. pF curves). The relationship between individual soil texture classes, bulk density, specific density, and organic matter content at certain soil suction ( $\mathrm{pF}$ values) were analyzed. The empirical models were described by multiple regression equation. The research covers 62 mineral forest soil layers of a diverse textured composition, from sand to clays. They were classified as Haplic Podzols and Cambisols representing pine and spruce ecosystems. For verification of the used method, calculated and measured values of total available water content were compared. The relationships between examined properties and the soil moisture content at certain $\mathrm{pF}$ value was provided statistically. The obtained data set can be a valuable representation of water retention characteristics and physical parameters of forest soil in pine and spruce ecosystems across Poland.
\end{abstract}

Keywords: soil water retention characteristic, soil density, organic matter, particle soil distributions

\section{Introduction}

The forestation index in Poland is approximately equal to $29.2 \%$ (according to GUS-Central Statistical Office-data from 31.12.2011). Poland has the largest forest area of the region after France, Germany, and Ukraine. Forests are commonly known for goods such as timber, food, fuel, and bio-products. Provision ecosystem services also include functions such as: watershed services - water quantity and quality, soil stabilization and erosion control, air quality, climate regulation and carbon sequestration, biodiversity,

*e-mail: edyta_hewelke@sggw.pl recreation and tourism, non-timber products, and cultural value. Soils as a habitat are one of the important factors that enable forestation development. Physically soil materials are simply described by several properties, i.e.: particle size distribution, soil bulk density, and particle density [1]. Besides mechanical composition of soils they are also defined using total porosity values, which enables us to determine maximal moisture content retained in the soils. The amount of the water kept inside the soils is often described in the form of the functional relationship between soil matrix potential (suction) and volumetric water content [2]. In a practical application this type of function is named soil water retention characteristic (SWRC) or pF curve [1, 3]. 
SWRC stays the most important hydrophysical soil characteristic for efficient use of water in agriculture and modelling of water and nutrient movement in a soil environment [4]. Thus the $\mathrm{pF}$ curves are useful for calculating available water capacity (AWC) in the soil [5] and are the basis for determining irrigation rate $[6,7]$. Despite developing measurement methodology of $\mathrm{pF}$ curve [3], the sourcing of these characteristics remains labor-intensive. Because transition from measurement procedures to practical utilization takes a relatively long time, indirect methods of $\mathrm{pF}$ curve calculation have been developed in the form of pedotransfer function (PTFs). The PTFs enable us to estimate $\mathrm{pF}$ curves from readily measurable soil properties such as sand silt and clay contents, bulk density, and organic matter content $[8,9]$. The influence of the basic soil physical properties on water retention and conductivity of the peat soils were presented in the studies performed by Gnatowski et al. [10, 11]. In order to find relationships between soil water retention characteristics, expressed in tabular form (moisture content values at predefined pressure head) or continuous, using an analytical description (i.e. Van Genuchten) [12], and the easy measurable physical features, linear multiple regression analysis is often used [13-15].

The PTF concept in the form of parameters can be incorporated in hydrological models [16, 17]. Another possibility of application of pedotransfer functions can be utilized as one in the decision support system for improving the natural water retained in river catchments with different cultivation practices [18].

However, despite the popularity of the pedotransfer functions, they should not be used outside the range of the soils for which they were developed [14]. This probably is because the predictability of the PTFs strongly depend on the data used for their calibration [19, 20]. Therefore, in order to evaluate existing PTFs the independent data set of the hydrophysical properties will always be eagerly anticipated [21]. The objective of the presented study was to analyze the basic soil physical properties and water retention characteristics of Haplic Podzols and Cambisols belonging to the pine and spruce ecosystems. Based on empirical data collected from the 10 soil profiles located in two different regions of Poland, point pedotransfer functions were developed. The proposed multiple linear regression models have been verified by comparison of the measured and calculated values of the available water capacity.

\section{Methods}

The investigated soil profiles are located at two different forest sites representing pine and spruce ecosystems. They were classified respectively as Haplic Podzols and Cambisols $[22,23]$. At each of the two ecosystems five independent soil profiles have been selected with the help of local forestry officers. From 10 profiles representing a total 62 soil layers the soil samples were collected in five replications in order to determine soil water retention characteristics. Additionally, from each of the soil horizons, bag sam- ples were taken for particle size distribution measurements. The $\mathrm{pF}$ curve characteristics were measured in the laboratory on undisturbed, standard $\left(100 \mathrm{~cm}^{-3}\right)$ soil samples using reference methods [24]. The moisture content values in the range of $\mathrm{pF}$ from 0 to 2 were determined on a sand table, whereas the amounts of water at the $\mathrm{pF}(2.7,3.4$, and 4.2) were measured in pressure chambers. The dry bulk density $\left(\rho_{b}\right)$ of each sample was determined by dividing the mass of the particles (oven dried $105^{\circ} \mathrm{C}$ ) by the volume of a core of the undisturbed saturated sample. The specific bulk density and particle size distributions for each of the analysed horizons were measured on the dried disturbed (bags) soil samples. The disturbed subsamples were also ignited in a muffle furnace at $550^{\circ} \mathrm{C}$ for $4 \mathrm{~h}$ to determine the loss-on-ignition that represents organic constituent contents. The soil particles were classified according to the previous standard of the Polish Society of Soil Science [25]. However, the particle size distribution data presented in this study can also be classified according to the current standards in Poland [23]. The oldest classification was only applied due to the possibility of a comparison with the data presented in the studies by Hewelke et al. [26]. The obtained data set was analyzed in order to study relationship between soil physical properties and to the determine their influence on moisture retention values at a predefined pressure head. Thus in the first stage of the analysis the simple regression method [27] was applied to establish dependency between particles of the soils and their physical properties and organic contents. To study the influence of the physical and organic matter contents on the $\mathrm{pF}$ curves, linear multiple regression analysis was applied. These attempts resulted in development point pedotransfer functions for each of the analyzed moisture contents values belonging to the $\mathrm{pF}$ curves. The general form of the empirical model, which includes more than one independent variable, can be written as [28]:

$$
Y=\beta_{0}+\beta_{1} X_{1}+\beta_{2} X_{2}+\ldots+\beta_{k} X_{k}+\varepsilon
$$

The dependent variable Y representing each moisture content value at a predefined pressure head can be written as a function of $\mathrm{k}$ independent variables $\mathrm{X}_{1}, \mathrm{X}_{2}, \ldots, \mathrm{X}_{\mathrm{k}}$. The $\varepsilon$ is an array of probabilistic random errors ( $\mathrm{e}_{\mathrm{i}}$ residuals) with a normal distribution. The $\mathrm{X}_{\mathrm{i}}$ values represent explanatory variables regarding physical properties, particle soil distribution, and soil organic matter content. The set of independent variables describing moisture contents were determined with the use of the backward stepwise elimination method [29]. Finally, the regression coefficients $\left(\beta_{\mathrm{i}}\right)$ were obtained by solving a set of simultaneous linear equations. The normal distribution of the residuals $\left(\mathrm{e}_{\mathrm{i}}\right)$ has been examined using a modified Smirnow-Kołgomorow test [30].

\section{Results and Discussion}

In Table 1 the value of the basic statistical moments characterizing the analyzed data are presented. The mean 
Table 1. Average overall water retention characteristics and basic statistics for considered soils.

\begin{tabular}{|c|c|c|c|c|c|c|c|}
\hline \multirow{2}{*}{ Statistics } & \multicolumn{7}{|c|}{ Measured volumetric water content (\%) at predefined values of $\mathrm{pF}$} \\
\cline { 2 - 8 } & $\theta_{\mathrm{pF}}=0.4$ & $\theta_{\mathrm{pF}}=1.0$ & $\theta_{\mathrm{pF}}=1.5$ & $\theta_{\mathrm{pF}}=2.0$ & $\theta_{\mathrm{pF}}=2.7$ & $\theta_{\mathrm{pF}}=3.4$ & $\theta_{\mathrm{pF}}=4.2$ \\
\hline$\mu$ & 45.47 & 40.85 & 35.52 & 18.57 & 12.59 & 8.39 & 3.02 \\
\hline$\sigma$ & 6.86 & 7.18 & 8.03 & 11.39 & 10.28 & 6.83 & 2.09 \\
\hline $\min$ & 33.50 & 26.4 & 16.20 & 4.60 & 1.00 & 0.70 & 0.40 \\
\hline $\max$ & 62.20 & 56.8 & 51.70 & 42.4 & 35.4 & 23.50 & 8.10 \\
\hline $\mathrm{CV}(\%)$ & 15.09 & 17.58 & 22.61 & 61.34 & 81.65 & 81.41 & 69.21 \\
\hline
\end{tabular}

$\mu$ - mean value of moisture content for the measured population of the forest soils, $\sigma-$ standard deviation, $\mathrm{CV}-$ coefficient of variability

values of the soil moisture contents decreasing together with increase of the pressure heads at each of the measured points of $\mathrm{pF}$ curves. At the state close to saturation of the soil $(\mathrm{pF}=0.4)$, the average values of soil moisture content amounted to about $45.5 \%$ and gradually decreased, reaching the value of permanent wilting point at about 3.0\%. At the same time, the range of variability of the moisture contents increased together with increase of the potential of the soil water. This diversification is clearly shown in values of coefficient of variability (CV). The $\mathrm{CV}$ results are generally in agreement with the data obtained from inde-


pendent measurements of $\mathrm{pF}$ curves of mineral soils prepared by other authors $[14,20,26]$. The same conclusions can be drawn from the water retention characteristics regarding organic soils [31]. Fig. 1 shows the water retention curves of the examined soils diversified in respect to the three distinguished soil texture classes (sandy, clayey, and silty). In the sandy soils a majority of the water volume occurs in the macropores, which correlates with a decrease of the range of the available water for plants (AWP is defined as a difference between moisture contents at $\mathrm{pF}=2$ and $\mathrm{pF}=2.7$ ) in this group. It should be emphasized that

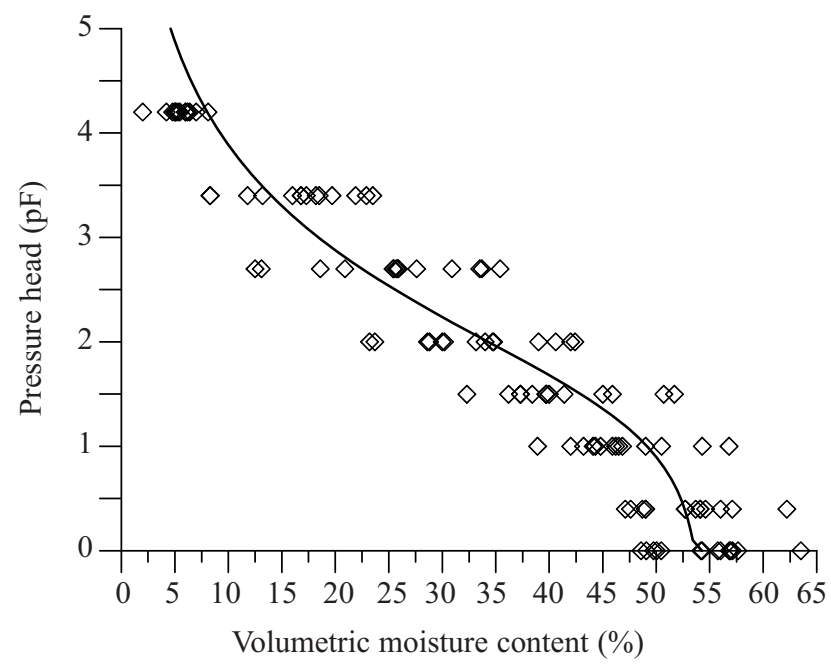

Fig. 1. The water retention curves representing analyzed textural classes: sandy, clayey, and silty soils. 
sandy soils are characterized by a large scatter in the measured $\mathrm{pF}$ curve data (Fig. 1). This may indicate the need for a correct formulation of empirical models that allow for estimating $\mathrm{pF}$ curve based on easily measurable soil characteristics even in this group of soils. In the two remaining soil classes the simultaneous effect of decrease of the amount of gravitational water and increase of the saturated water contents ( $\theta_{\mathrm{s}}$ moisture contents at full capacity) was observed. This can be associated with an increase of the fine fraction contents and higher organic contents in these groups in comparison to sandy soils. This can also be confirmed with the help of data presented in Fig. 2. The increase of the silt fraction was well correlated with increases of organic matter contents. Simultaneously the high amount of sand fraction reflects on low organic matter content. The relationships between bulk density, specific density as well as organic matter content, and sand fraction content presented in Fig. 2 had a linear character. However, the analogous compounds with the contents of silt fraction rather represent the nonlinearly dependent. The coefficients of determination (Fig. 2) show that the established functions were statistically significant.

The presented data indicate that the considered soils cover a wide range of particle size distributions. This is especially visible in the range of silt content variability (Fig. 2). The measured data of these particles ranged from 0 (sandy soils) to almost $40 \%$ in the silty soils. In the presented database also bulk densities were widely varied. In the soils with low organic matter contents (sandy soils) the $\rho_{\mathrm{b}}$ values were less than $1 \mathrm{~g} \cdot \mathrm{cm}^{-3}$. This accounted for about $7 \%$ of the analyzed population similarly to the data for the German forest soils [5]. The greatest parts of the analyzed population (about $58 \%$ ) were soils with a density of 1.3 to $1.7 \mathrm{~g} \cdot \mathrm{cm}^{-3}$. The range of the $\mathrm{C}_{\text {org }}$ values was changing from 0 to about $11.3 \%$ and was slightly lower than those presented by Teepe et al. [5]. Thus the presented data seems to be
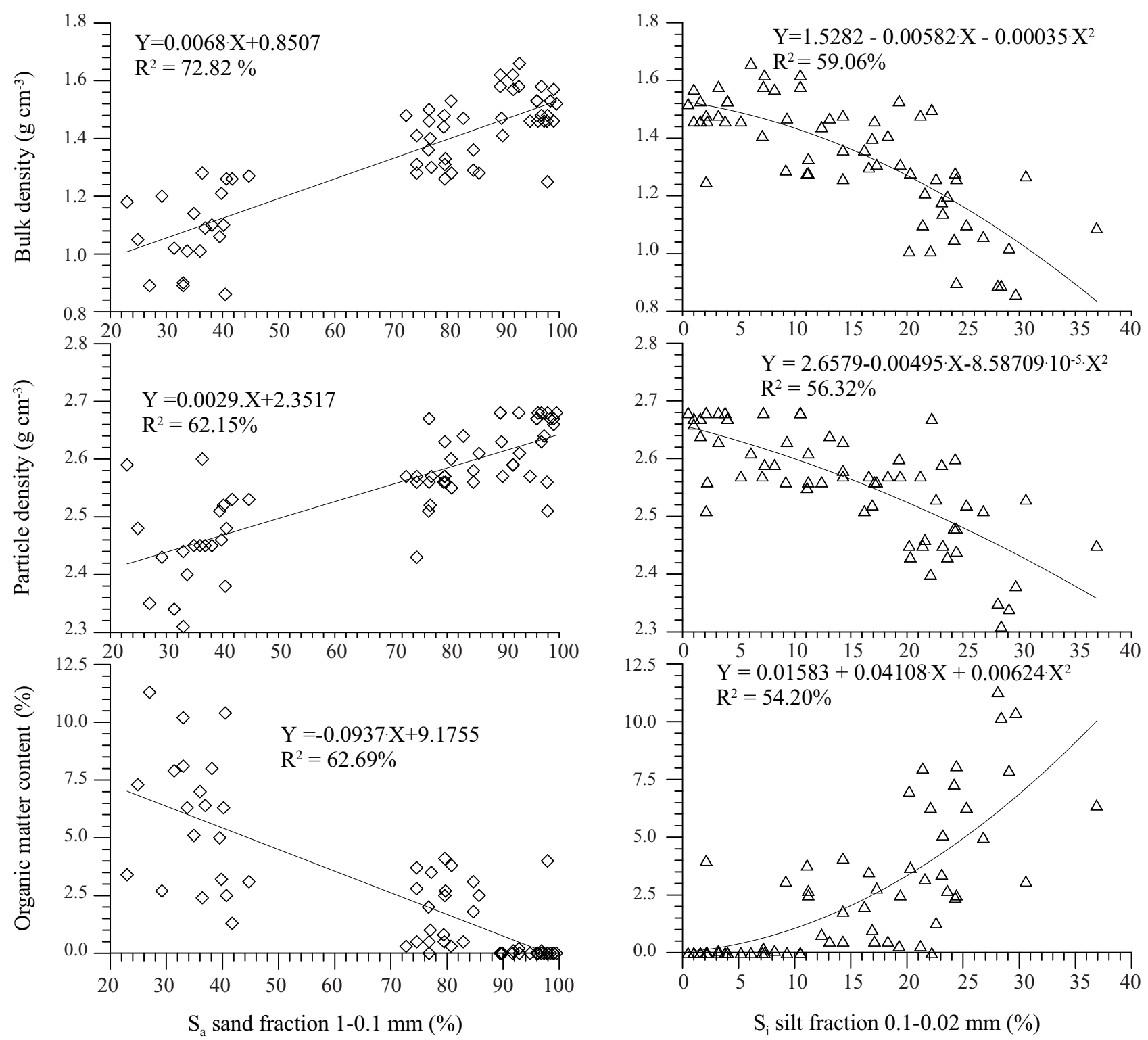

Fig. 2. Relationships between soil basic properties. 
Table 2. Empirical models of moisture contents at predefined values of $\mathrm{pF}$ and statistics of Kołmogorow-Smirnov test in the analysis of residual for developed regression equations.

\begin{tabular}{|c|c|c|c|c|}
\hline No. & Empirical $\mathrm{pF}$ curves models - point of pedotransfer functions & $\mathrm{R}^{2}$ & $\operatorname{tg} \beta$ & $\lambda_{\mathrm{K}-\mathrm{S}}$ \\
\hline 1 & $\begin{aligned} \theta_{\mathrm{pF}=0.4} & =90.0056-33.4052 \cdot \rho_{\mathrm{b}}-1.62435 \cdot \mathrm{S}_{\mathrm{i}}-0.26377 \cdot \mathrm{S}_{\mathrm{i}} \cdot \rho_{\mathrm{b}} \\
& +0.77502 \cdot \mathrm{S}_{\mathrm{i}} \cdot \rho_{\mathrm{p}}\end{aligned}$ & 98.23 & 0.999 & 0.582 \\
\hline 2 & $\begin{aligned} \theta_{\mathrm{pF}=1.0} & =160.643-43.1639 \cdot \rho_{\mathrm{p}}+0.672707 \cdot \mathrm{S}_{\mathrm{a}}-7.3989 \cdot \mathrm{S}_{\mathrm{i}}-0.52663 \cdot \mathrm{S}_{\mathrm{a}} \cdot \rho_{\mathrm{b}} \\
& +2.77686 \cdot \mathrm{S}_{\mathrm{i}} \cdot \rho_{\mathrm{p}}+0.0714351 \cdot \mathrm{S}_{\mathrm{i}} \cdot \mathrm{C}_{\mathrm{org}}-1.03448 \cdot \mathrm{C}_{\mathrm{org}} \cdot \rho_{\mathrm{b}}\end{aligned}$ & 89.39 & 0.997 & 0.679 \\
\hline 3 & $\begin{aligned} \theta_{\mathrm{pF}=1.5} & =325.823-109.108 \cdot \rho_{\mathrm{p}}-2.4174 \cdot \mathrm{C}_{\mathrm{org}}-13.6859 \cdot \mathrm{S}_{\mathrm{i}}-0.64342 \cdot \mathrm{S}_{\mathrm{a}} \cdot \rho_{\mathrm{b}} \\
& +0.333195 \cdot \mathrm{S}_{\mathrm{a}} \cdot \rho_{\mathrm{p}}+5.17961 \cdot \mathrm{S}_{\mathrm{i}} \cdot \rho_{\mathrm{p}}+0.128288 \cdot \mathrm{S}_{\mathrm{i}} \cdot \mathrm{C}_{\mathrm{org}}\end{aligned}$ & 83.56 & 0.992 & 0.720 \\
\hline 4 & $\theta_{\mathrm{pF}=2.0}=-87.9967+122.001 \cdot \rho_{\mathrm{b}}-213.517 \cdot \ln \left(\rho_{\mathrm{b}}\right)+1.63628 \cdot \ln \left(\rho_{\mathrm{b}}\right) \cdot \mathrm{S}_{\mathrm{pl}}$ & 90.58 & 0.975 & 0.476 \\
\hline 5 & $\begin{aligned} \theta_{\mathrm{pF}=2.7} & =998.161-553.099 \cdot \rho_{\mathrm{b}}-366.053 \cdot \rho_{\mathrm{p}}-12.1134 \cdot \mathrm{C}_{\mathrm{org}}-15.5097 \cdot \mathrm{S}_{\mathrm{i}} \\
& -0.238188 \cdot \mathrm{S}_{\mathrm{a}} \cdot \rho_{\mathrm{b}}+5.76494 \cdot \mathrm{S}_{\mathrm{i}} \cdot \rho_{\mathrm{p}}+0.232813 \cdot \mathrm{S}_{\mathrm{i}} \cdot \mathrm{C}_{\mathrm{org}} \\
& +6.81292 \cdot \mathrm{C}_{\mathrm{org}} \cdot \rho_{\mathrm{b}}+211.562 \cdot \rho_{\mathrm{p}} \cdot \rho_{\mathrm{b}}\end{aligned}$ & 91.81 & 0.968 & 0.674 \\
\hline 6 & $\begin{aligned} \theta_{\mathrm{pF}=3.4} & =624.813-348.437 \cdot \rho_{\mathrm{b}}-229.55 \cdot \rho_{\mathrm{p}}-7.62926 \cdot C_{\mathrm{org}}-9.33429 \cdot \mathrm{S}_{\mathrm{i}} \\
& -0.159606 \cdot \mathrm{S}_{\mathrm{a}} \cdot \rho_{\mathrm{b}}+3.4551 \cdot \mathrm{S}_{\mathrm{i}} \cdot \rho_{\mathrm{p}}+0.147551 \cdot \mathrm{S}_{\mathrm{i}} \cdot C_{\mathrm{org}} \\
& +4.37701 \cdot C_{\mathrm{org}} \cdot \rho_{\mathrm{b}}+134.015 \cdot \rho_{\mathrm{p}} \cdot \rho_{\mathrm{b}}\end{aligned}$ & 91.98 & 0.969 & 0.845 \\
\hline 7 & $\begin{aligned} \theta_{\mathrm{pF}=4.2} & =9.55007-0.0551704 \cdot \mathrm{S}_{\mathrm{a}} \cdot \rho_{\mathrm{b}}+0.26058 \cdot \mathrm{S}_{\mathrm{i}} \cdot \rho_{\mathrm{b}}-0.180619 \cdot \mathrm{S}_{\mathrm{i}} \cdot \rho_{\mathrm{p}} \\
& +0.0149768 \cdot \mathrm{S}_{\mathrm{i}} \cdot \mathrm{C}_{\text {org }}\end{aligned}$ & 89.08 & 0.964 & 0.720 \\
\hline
\end{tabular}

$\mathrm{R}^{2}$ - coefficient of determination (\%); $\operatorname{tg} \beta$ - the slope of a straight line between the measured and modeled values of the soil moisture contents; $\lambda_{\alpha}=1.354$ critical value of the Kołmogorow-Smirnov test at significance level $\alpha=0.05 ; \mathrm{S}_{\mathrm{a}}, \mathrm{S}_{\mathrm{i}}, \mathrm{S}_{\mathrm{pl}}(\%) ; \rho_{\mathrm{b}}, \rho_{\mathrm{p}}\left(\mathrm{g} \cdot \mathrm{cm}^{-3}\right) ; \mathrm{C}_{\mathrm{org}}(\%)$.

representative of wide range of soil water characteristics and particle size distribution. Therefore, it is believed that the obtained data set can be a valuable representation of water retention characteristics and physical parameters of the forest soils in the pine and spruce ecosystems across Poland. The preliminary analysis of the collected data enables us to conduct the multiple regression analysis in order to develop point pedotransfer functions separately for each of the considered moisture retention values.

Table 2 presents the results of statistical analysis in the form of empirical equations representing pedotransfer functions for the select forest soils. Analyzing the empirical

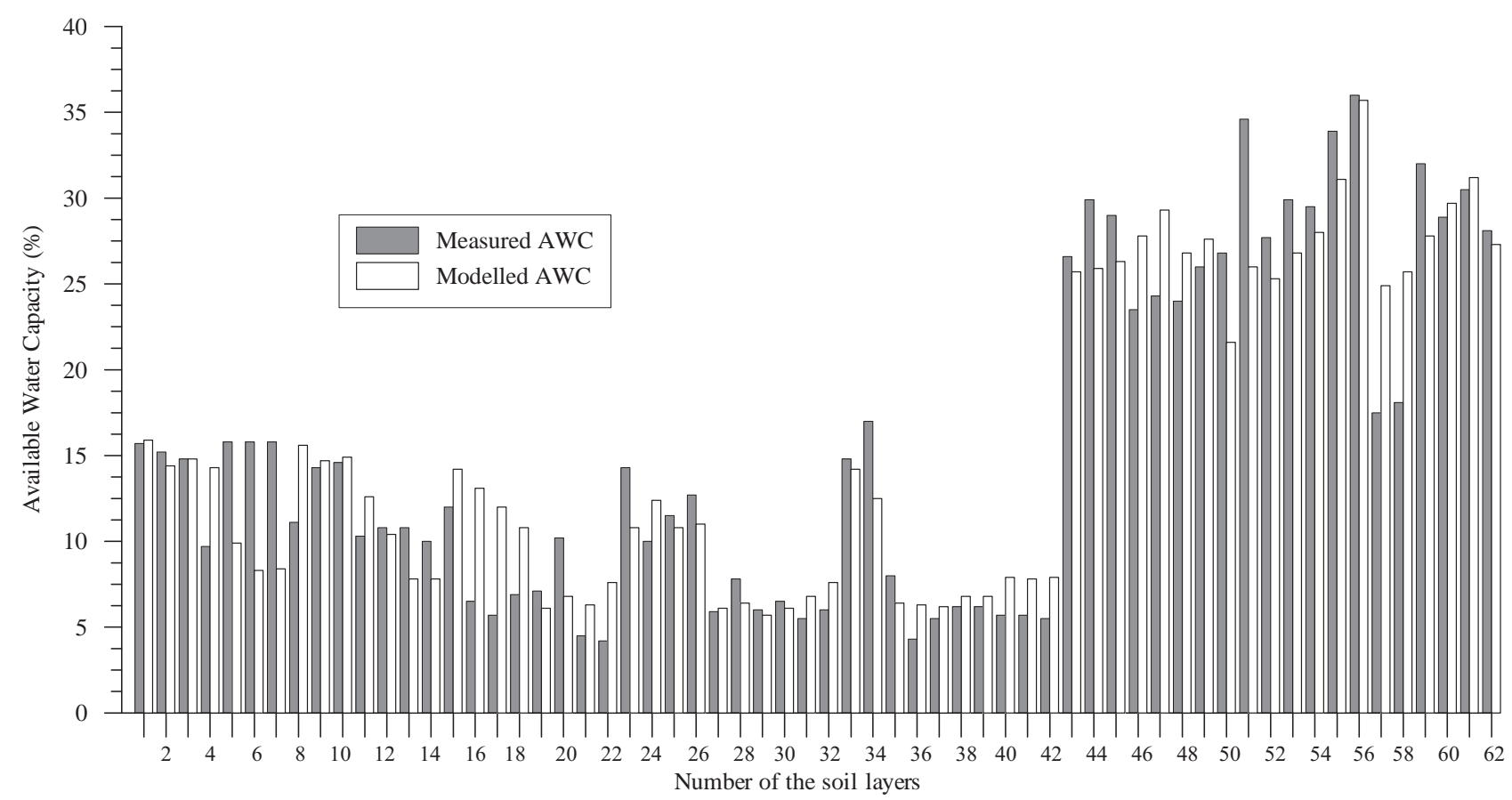

Fig. 3. Measured and modelled values of available water capacity for each soil layer. 
equation presented in Table 2, it can be concluded that in the case of the forest soils occurring in the pine and spruce ecosystems the bulk density $\left(\rho_{\mathrm{b}}\right)$, specific density $\left(\rho_{\mathrm{p}}\right)$, organic matter content $\left(\mathrm{C}_{\text {org }}\right)$, sand fraction from 1 to $0.1 \mathrm{~mm}$ $\left(\mathrm{S}_{\mathrm{a}}\right)$, silt fraction from 0.1 to $0.02 \mathrm{~mm}\left(\mathrm{~S}_{\mathrm{i}}\right)$, and content of particles smaller than $0.02 \mathrm{~mm}\left(\mathrm{~S}_{\mathrm{pl}}\right)$ had essential impact on soil water retention characteristics. The obtained results in the forms of empirical equations generally are in agreement with data presented in the literature $[5,15,29]$. However, it should be stressed that forecasting of the field capacity, commonly assumed at $\mathrm{pF}=2$, which is a very important soil moisture status $[6,32]$, the $\mathrm{S}_{\mathrm{pl}}$ fraction content was required.

The evaluation of quality of fit between modelled and measured retention characteristics were examined by coefficient of determination $\left(\mathrm{R}^{2}\right)$. For each of the developed equations these values were in the range from 84 to $98 \%$. This means that for soil populations with similar properties to the presented data set the obtained empirical equations can be applied for assessment of the soil water retention characteristics indirectly. Moreover, the slopes of the straight lines between calculated and measured $\mathrm{pF}$ curves were determined and for all of the analyzed cases (according to the equations presented in Table 2) their values ranged from 0.9645 to 0.9997 (close to the optimal value of 1). To fulfil the criteria of the multiple regression analysis the distribution of the residuals were studied. The normality of the errors from the models has been tested using $\lambda$ Kołgomorow-Smirnov test. The empirical $\lambda$ values are presented also in Table 2. In all developed equations the empirical statistics were lower than critical value of this test. Thus it can be assumed that residuals calculated from models come from normal distribution.

Evaluation of the PTF functions presented in Table 2 was performed by comparison measured and modelled of the available water capacity (AWC). For the needs of this analysis the AWC was defined as difference between moisture contents measured at two matrix potentials: $\mathrm{pF}=2.0$ and $\mathrm{pF}=4.2$. Thus, forecasted value of the available water capacity was determined with the use of equations 4 and 7 (Table 2). For comparison of these two hydrophysical properties the coefficient of correlation (r), slope of the linear relation, and root mean square error (RMSE) have been determined. From the obtained statistical results we can conclude that $r$ value was relatively high $(0.930)$. The slope coefficient between measured and calculated AWC values was close to 1 and its value was determined as 0.9644 . This indicates that forecasted AWC values in considered populations can be slightly underestimated in comparison with measured data. However, the RMSE value is equal to about 3.5\%, showing that developed PTF functions can be applied for prediction of the available water capacity for select forest soils with acceptable level of accuracy. Fig. 3 presents the measured and calculated values of the available water capacity (AWC) for all of the considered soil layers.

The obtained results of the predictive values of the AWC for select forest soils generally are comparable with the modelled data for the German condition [5]. This was especially visible in the case of soils with bulk density lower than $1.45 \mathrm{~g} \cdot \mathrm{cm}^{-3}$. However, in the soils with bulk density above $1.45 \mathrm{~g} \cdot \mathrm{cm}^{-3}$ the available water capacities were two times lower than those presented by Teepe et al. [5]. These discrepancies resulted mainly from the meaning of the AWC. For the German conditions this value was established as the difference between moisture contents at $\mathrm{pF}=1.8$ and $\mathrm{pF}=4.2$. Thus in the case of the soils with low organic matter contents (sandy soils) the moisture content at $\mathrm{pF}=2.0$ can be much lower than at $\mathrm{pF}=1.8$. Therefore the selection of this point of $\mathrm{pF}$ curve can influence proper estimation of available water capacity.

\section{Conclusions}

The investigated mineral soils were characterized by a relatively wide-range of variability of physical and waterretention properties. The conviction of that fact allowed the development of point pedotransfer functions for predicting the soil moisture contents at certain, predefined pressure heads. Application of the multiple regression analysis showed that essential impact on the water retention curves had bulk density, specific density, organic matter content, and textured composition represented by sand and silt fractions, and content of particles smaller than $0.02 \mathrm{~mm}$. The content of fine fraction $\left(\mathrm{S}_{\mathrm{pl}}\right)$ is especially important for indirect determination of the moisture content at field capacity. For all obtained empirical equations the high values of the determination coefficients ( $\mathrm{R}^{2}$ from 84 to $98 \%$ ) were observed. The conducted residuals analysis confirms the hypothesis that they come from normal distribution. The validation stage of the obtained pedotransfer functions was performed with the application of the available water capacity values. For the analyzed population of the forest soils the root mean square error of the estimated AWC values was 3.5\%. Thus the obtained pedotransfer functions can be used for indirect determination of the soil water retention characteristics for forest soils with similar properties.

\section{References}

1. JURY W.A., GARDNER W.R., GARDNER W.H. Soil physics $5^{\text {th }}$ ed. John Wiley \& Sons: New York, pp. 29-70, 1991.

2. ZAWADZKI S. Laboratory determination of the retention capacity of soil formations. Wiad. IMUZ 11, (2), 11, 1973 [In Polish].

3. SCHELLE H., HEISE L., JÄNICKE K., DURNER W. Water retention characteristics of soils over the whole moisture range: a comparison of laboratory methods. Eur. J. Soil Sci. 64, 814, 2013.

4. VOGT R.D., SEIP H.M., OREFELLEN H., SKOTTE G., IRGENS C., TYSZKA J. Trends in Soil Water Composition at a Heavily Polluted Site - Effects of Decreased SDeposition and Variations in Precipitation. Water Air Soil Poll. 130, (1-4), 1445, 2001.

5. TEEPE R., DILLING H., BEESE F. Estimating water retention curves of forest soils from soil texture and bulk density. J. Plant Nutr. Soil Sci., 166, 111, 2003. 
6. ASCHONITIS V.G., ANTONOPOULOS V.Z., LEKAKIS E.H., LITSKAS V.D., KOTSOPOULOS S.A., KARAMOUZIS D.N. Estimation of field capacity for aggregated soils using changes of the water retention curve under the effects of compaction. Eur. J. Soil Sci., 64, 688, 2013.

7. ŻAKOWICZ S. Principles of irrigation technology of restoration municipal wastes landfills. Treatises an Monographs SGGW Warszawa, pp. 66-80, 2010 [In Polish].

8. RAWLS W.J., BRAKENSIEK D.L. Estimation soil water retention from soil properties. J. Irrig. Drain. Div. 108, (2), 166,1982

9. TIETJE O., TAPKENHINRICHS M. Evaluation of pedotransfer functions. Soil Sci. Soc. of Am. J., 57, 1088, 1993.

10. GNATOWSKI T., SZEJBA D., OLESZCZUK R., BRANDYK T., SOSULSKI T. The influence of physical and chemical properties on the water retention of peat soils from the Biebrza River Valley [In:] Brandyk T., Szajdak L., Szatyłowicz J. (Ed.). Physical and chemical properties of the organic soils. SGGW Warszawa, pp. 65-74, 2006 [In Polish].

11. GNATOWSKI T., SZATYLOWICZ J., BRANDYK T., KECHAVARZI C. Hydraulic properties of fen peat soils in Poland. Geoderma 154, (3-4), 188, 2010.

12. GENUCHTEN VAN M.TH. A closed-form equation for predicting the hydraulic conductivity of unsaturated soils. Soil Sci. Soc. Am. J. 44, 892, 1980.

13. VARALLYAY G., MIRONENKO E.V. Soil water relationships in saline and alkali conditions. [In:] V.A. Kovda, I. Szabolces (Ed.), Modeling of Salinization and Alkalization. Agrokemia es Talatjan 28, (Suppl.), 33, 1979.

14. WÖSTEN J.H.M., LILLY A., NEMES A., LE BAS C. Development and use of a database of hydraulic properties of European soils. Geoderma 90, 169, 1999.

15. MIHÁLIKOVÁ M., MATULA S., DOLEŽALF. HYPRESCZ - Database of Soil Hydrophysical Properties in the Czech Republic. Soil \& Water Res., 8, 34, 2013.

16. SIMUNEK, J., SEJNA M., VAN GENUCHTEN M. TH. The HYDRUS-2D software package for simulating twodimensional movement of water, heat, and multiple solutes in variably saturated media. Version 2.0, IGWMC - TPS 53, International Ground Water Modeling Center, Colorado School of Mines, Golden, Colorado, 251, 1999.

17. KROES J.G., VAN DAM J.C., GROENENDIJK P., HENDRIKS R.F.A., JACOBS C.M.J. SWAP version 3.2. Theory description and user manual, Alterra Report 1649(02), Wageningen, 284, 2008.
18. MROZIK D.K., PRZYBYŁA C. An attempt to introduce cultivation and planning measures into the decision-making process in order to improve water - retaining capacity of river catchment. Pol. J. Environ. Stud. 22, (6), 1767, 2013.

19. SCHAAP M.G., LEIJ F.J., VAN GENUCHTEN M.TH. Rosetta: A computer program for estimating soil hydraulic parameters with hierarchical pedotransfer functions. J. Hydrol. 251, 163, 2001.

20. SCHAAP M.G., LEIJ F.J. Using neural networks to predict soil water retention and soil hydraulic conductivity. Soil Till. Res., 47, 37, 1998.

21. WAGNER B., TARNAWSKI V.R., HENNINGS V., MÜLLER U., WESSOLEK G., PLAGGE R. Evaluation of pedo-transfer functions for unsaturated soil hydraulic conductivity using an independent data set. Geoderma 102, 275, 2001.

22. WRB. 2006. World reference base for soil resources, $2^{\text {nd }}$ edition, World Soil Resources Reports 103, FAO, Rome.

23. Polish Soil Classification 2011. Soil Science Annual 62, (3), 5, 2011 [In Polish].

24. KLUTE A. Water retention: laboratory methods. In: Methods of soil analysis; Part 1: Physical and mineralogical methods, Agronomy Monographs no 9, A., Klute (ed.), ASA and SSA: Madison, Wisconsin, pp. 635-662, 1986.

25. BN-178/9180-11: 1978. Soils and mineral compositions [In Polish].

26. HEWELKE P., GNATOWSKI T., ŻAKOWICZ S. The analysis of water retention capacity of mineral soils. Acta Sci. Pol., Formatio Cirtcumiectus 12, (1), 43, 2013.

27. ZIELIŃSKI W. Regression analysis. Fundacja Rozwój SGGW, 105, 1998 [In Polish].

28. McCLAVE J.T., DIETRICH F.H. Statistics $4^{\text {th }}$ ed. Dellen Publishing Company: San Francisco, pp. 759-822, 1988.

29. LIAO K.H., XU S.H., WU J.Ch., JI S.H., LIN Q. Assessing soil water retention characteristics and their spatial variability using pedotransfer functions. Pedosphere 21, (4), 413, 2011.

30. DOMAŃSKI C. Statistical tests. PWE: Warszawa, pp 6372, 1990 [In Polish].

31. GNATOWSKI T., OLESZCZUK R., SZATYŁOWICZ J. Analysis of retention and hydraulic properties in peat moorsh soil. Pol. J. Environ. Stud. 17, (3A), 211, 2008.

32. CEJPEK J., KURAŻ V., FROUZ J. Hydrological properties of soils in reclaimed and unreclaimed sites after brown-coal mining. Pol. J. Environ. Stud. 22, (3), 645, 2013. 
